\title{
SOURCES OF VARIATION IN THE BIRTH WEIGHT OF AYRSHIRE CALVES
}

\author{
Vappu Kossil a and PirkKo TAskinen \\ Department of Animal Husbandry, University of Helsinki
}

Received May 30, 1969

Beef producing cattle is very rare in Finland. Most of the beef in the Finnish meat market originates from the native dairy cattle husbandry. Yet, only a few years ago, most surplus dairy calves were disposed of at an age of a few days. Now, however, interest in dairy-beef production has greatly increased. According to HAFEz (1968, p. 239), dairy cows give birth to larger calves than beef cows of similar weight. This phenomenon is obviously largely due to the differences in the hormonal constitution of the two types of cattle. Compared to the beef cow, the dairy cow is superior in milking ability and she tends to convert the nutrients from the feeds into constituents of milk rather than into flesh. However, it is possible that the hormonal efficiency of a dairy cow influences to a certain degree the birth weight and viability of the calf. Presumably dairy cows that give birth to large calves are better feed converters and milkers than those giving birth to small calves. If this is so, the efficiency of animal production can be increased along these lines by selecting dams of the former kind, since their offspring are usually not only more viable and healthier, but also grow faster and yield more economic profits.

There are a number of factors such as the breed (ref. NIELSEN 1964), season of calving (Tyler et al. 1947), length of gestation (MäKelä \& Otttila 1955, ANdersen 1962, MukerJi \& EKKa 1962), size of the dam (KNAPP et al. 1940, Venge 1948, Mäkelä 1959, Novy 1963), size of the sire (Foote et al. 1959, NIELSEN 1964), number of calvings of the dam (Venge 1948, Braude \& Walker 1949, BenNet 1959), nutritional factors, especially during the last half of the gestation (Frтch et al. 1925), sex of the calf, and the number of the fetuses (Roy 1955, Mäkelä 1959, Petcu \& Calotoru 1967) that are known to have some influence on the birth weight of the calves. It is possible, for instance, that an increase in the length of the dry period in dairy cows increases the availability of nutrients for the development of the fetus thus having a positive effect on the birth weight of the calf. The number of services per gestation, an indicator of the reproductive capacity in cows, on the other hand, may be assumed to be negatively related to the birth weight of the 
calf. If the growth rate of the calf in utero is parallel with the intensity of the development of the milk secreting cells in the udder during the later part of gestation, a dam that produces a large calf may also produce more milk as compared with one giving birth to a small calf.

The object of the present study has been to find out whether and to what degree the birth weight of the Ayrshire calf is related to the size of the dam, to the length of the dry period prior to calving, to the number of services per gestation, and/or to the milk yield of the lactation period subsequent to calving. At the same time also the effects of the season of birth, the number of the dam's calvings, and the sex of the calf have been investigated.

\section{Material and methods}

According to the Finnish dairy cow testing system, a cow is considered a regular if her calving intervals remain less than 15 months. Data comprising 56 regular, well-fed Ayrshire cows in better than average condition and having from two to eight complete consecutive lactation records were selected from the Viik Experimental Farm dairy herd (Table 2). All cows had calved each time one fulltime, healthy calf. The following details were listed for each cow: 1) date and 2) number of calving, 3) sex and 4) birth weight of each calf, 5) live weight and 6) degree of fatness of the cow after five days of each calving, 7) number of services per the gestation from which the calf was born, 8) number of days dry prior to calving (first calvers excluded), and 9) $4 \%$ fat corrected milk (FCM) yield during the complete lactation period subsequent to the birth of the calf in question. The data consisting altogether of 225 calvings was grouped according to the sex of the calf, the season of birth, and the number of dam's calving (Tables 1 \& 2). The statistical calculations were made according to Croxton \& Cowden (1955).

\section{Results}

The birth weight of the calves in this study ranged from 24 to $49 \mathrm{~kg}$ in males and from 23 to $46 \mathrm{~kg}$ in females. The live weight of the dams ranged from 378 to $680 \mathrm{~kg}$, the degree of fatness from normal to very fat, the number of services per gestation from 1 to 6 times, the length of the dry period from 20 to 160 days and the FCM yield from 3953 to $9101 \mathrm{~kg}$.

$\mathrm{E} f \mathrm{fe} \mathrm{ct}$ of s ex. As expected, the mean birth weight of all male calves $(35.2 \mathrm{~kg})$ was higher compared with the corresponding value $(33.4 \mathrm{~kg})$ in females (Table 1), the sex difference of $1.8 \mathrm{~kg}$ being significant at the level of $\mathrm{P}<0.005$.

E ffe c t of s e a s o n. Data consisting of 225 calvings was divided into four groups according to the birth month: January-March, April-June, July-September, and OctoberDecember (Table 1). The pasture season had begun approximately on May 20th lasting from 100 to 120 days, but the cows calving in June were usually kept in the barn until they had calved. Results in Table 1 show that the mean birth weight of both sexes of calves was lowest $(32.3 \mathrm{~kg})$ in July-September and highest $(35.5 \mathrm{~kg}$ ) in April-June, the difference between these two values being significant at the level $\mathrm{P}<0.001$. The mean live weight of the dams was also lowest during July-September (Table 1). 
When the birth weight of the calf was calculated as a percentage of the live weight of the dam, the following results were obtained:

The birth weight of the calf as a percentage from the live weight of the dam ( $N=$ number of cases)

\begin{tabular}{|c|c|c|c|c|c|c|}
\hline \multirow[t]{2}{*}{ Season of birth } & \multicolumn{2}{|c|}{ Males } & \multicolumn{2}{|c|}{ Females } & \multicolumn{2}{|c|}{ Both sexes } \\
\hline & $\mathrm{N}$ & $\%$ & $\mathrm{~N}$ & $\%$ & $\mathrm{~N}$ & $\%$ \\
\hline January-March & 37 & 6.83 & 31 & 6.70 & 68 & 6.78 \\
\hline April-June & 33 & 7.13 & 40 & 6.52 & 73 & 6.80 \\
\hline July-September & 22 & 7.38 & 32 & 6.40 & 54 & 6.80 \\
\hline October-December & 31 & 6.08 & 26 & 6.58 & 57 & 6.80 \\
\hline All & 123 & 7.05 & 129 & 6.55 & 252 & 6.80 \\
\hline
\end{tabular}

The above results show that season had an opposite effect on the relative birth weight of the males as compared with the females, but after both sexes were combined, the seasonal effect was not observable. As a whole, the male calves were heavier $(7.05 \%)$ in relation to their dam's live weight than the female ones $(6.55 \%)$. It was also noted that small cows produced relatively heavier calves than large cows, irrespective of age.

The cows that were bred during the first half of the year, ie. those bred to calve in October-March, needed slightly more services per gestation than those bred during the last half of the year (Table 1). The average length of the dry period was shortest in JulySeptember and longest in January-March, this seasonal trend being non-significant. The season of calving had only a slight effect on the FCM yield, the lowest level occurring during the lactation period following calving in April-June (Table 1).

$\mathrm{Effect}$ of $\mathrm{calving} \mathrm{number}$. The present material was also divided into six groups according to the number of the calving of the dam. The birth weight of the male calves increased from the first up to the 5th calving, whereas in the females the highest average birth weight occurred already at the 3rd calving (Table 2). In both sexes significantly heavier calves were born from the 3rd to the 5 th calving as compared to the calves born from the 1st, 2nd, and 6th or subsequent calvings.

The relative birth weight, again, tended to be higher at the first three calvings as compared with later calvings. This can be seen from the compilation below:

The birth weight of the calf as a percentage of the live weight of the dam ( $\mathrm{N}=$ number of cases)

\begin{tabular}{lcccccc} 
No. of calving & \multicolumn{2}{c}{ Males } & \multicolumn{2}{c}{ Females } & \multicolumn{2}{c}{ Both sexes } \\
& N & $\%$ & N & $\%$ & N & $\%$ \\
1. & 29 & 7.44 & 27 & 6.69 & 56 & 7.08 \\
2. & 28 & 6.96 & 28 & 6.80 & 56 & 6.88 \\
3. & 21 & 7.07 & 31 & 6.77 & 52 & 6.89 \\
4. & 18 & 6.80 & 19 & 6.22 & 37 & 6.51 \\
5. & 17 & 7.05 & 10 & 6.26 & 27 & 6.76 \\
6. or later & 10 & 6.53 & 14 & 5.93 & 24 & 6.18
\end{tabular}

It shows also that the male calves at the first calving have been the heaviest in relation to the size of their dam and the female calves at the 6 th or later calvings have been the lightest. 


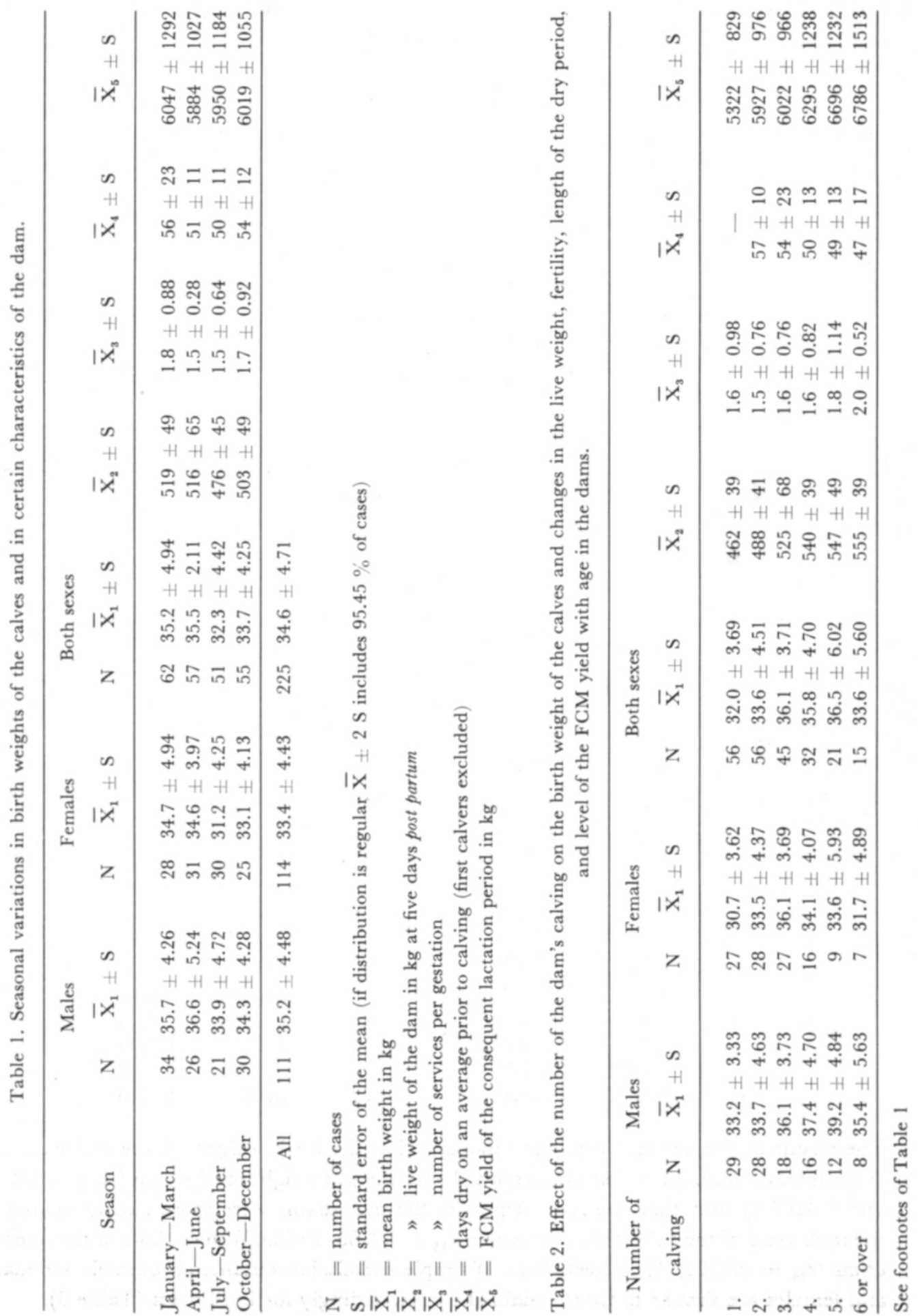


The live weight as well as the level of the FCM yield of the dams has risen with increasing numbers of the calvings (Table 2). Also, the number of services per gestation tended to increase with age, whereas the length of the dry period prior to calving tended to decrease correspondingly.

$\mathrm{Stat}$ istical study. The relative importance of various factors on the birth weight of the calves was ascertained by calculating the coefficients of simple and partial correlations for the following variables: the birth weight in $\mathrm{kg}\left(\mathrm{X}_{1}\right)$, the live weight of the dam in $\mathrm{kg}\left(\mathrm{X}_{2}\right)$, the number of services per gestation $\left(\mathrm{X}_{3}\right)$, the length of the dry period in days $\left(\mathrm{X}_{4}\right)$ (first calvers excluded), and the level of the FCM yield in $\mathrm{kg}$ during the lactation period following the calving in question $\left(\mathrm{X}_{5}\right)$. The coefficients of correlations thus obtained have been summarized in Table 3 .

Coefficients of correlation in Table 3 demonstrate that, among the factors under observation, the live weight of the dam had the greatest and the most highly significant $(\mathrm{P}<0.001)$ influence on the birth weight of the calf $\left(\mathrm{r}_{12}=0.4081\right)$ even when other factors were held constant $\left(\mathrm{r}_{12.345}=0.4022\right)$.

Number of services per gestation was hardly at all correlated with the birth weight of the calves $\left(r_{13}=0.0342, r_{13.245}=-0.0260\right)$; the length of the dry period had a slight positive, but non-significant effect on the birth weight $\left(r_{14}=0.1210, r_{14.235}=0.1235\right)$, and the FCM yield of the lactation period subsequent to calvings was hardly at all related to the birth weight $\left(r_{15}=0.0625, r_{15.234}=0.0111\right)$.

Neither the number of services per gestation nor the length of the dry period were significantly related to the live weight of the cows, whereas a fairly significant positive correlation was obtained between the live weight of the cows and the FCM yield $\left(r_{25}=\right.$ $\left.0.1734, \mathrm{r}_{25.134}=0.1474, \mathrm{P}<0.05\right)$.

Other observable trends, even though non-significant, were the following: the length of the dry period tended to increase with an increasing number of services per gestation $\left(\mathrm{r}_{34}=0.1121\right)$; the milk yield tended to be higher in cows with increasing number of services per gestation $\left(r_{35}=0.1250\right)$; the length of the dry period was negatively correlated with the milk yield of the subsequent lactation $\left(r_{45}=-0.1330\right)$.

The coefficients of simple correlation between the factors previously mentioned were also calculated separately for the male and female calves:

$\begin{array}{llllll} & \text { Males } & \text { Females } & & \text { Males } & \text { Females } \\ & & & & & \\ \mathrm{r}_{12} & 0.4420^{* * *} & 0.4162^{* * *} & \mathrm{r}_{24} & 0.0980 & 0.0048 \\ \mathrm{r}_{13} & 0.0125 & 0.0218 & \mathrm{r}_{25} & 0.2205 * & 0.0918 \\ \mathrm{r}_{14} & 0.1109 & 0.0823 & \mathrm{r}_{34} & 0.0996 & 0.1019 \\ \mathrm{r}_{15} & 0.0737 & 0.0596 & \mathrm{r}_{35} & 0.1250 & 0.0237 \\ \mathrm{r}_{23} & 0.1542 & 0.0824 & \mathrm{r}_{45} & -0.1061 & -0.1510\end{array}$

The results in the above compilation indicate that the birth weights of the males as well as the females were quite closely correlated with the live weights of the dam $\left(r_{12}=0.4420\right.$ o and 0.4162 o) and that the live weights of the male-dams were more closely related to the milk yield of the subsequent lactation $\left(r_{25}=0.2205, P<0.05\right)$ than those of the femaledams $\left(r_{25}=0.0918\right)$. The coefficients of simple correlation obtained separately for males and females are similar to those obtained correspondingly for both sexes (Table 3). 
Table 3. Coefficients of simple and partial correlations between the birth weight in $\mathrm{kg}\left(\mathrm{X}_{1}\right)$, live weight of the dam in $\mathrm{kg}\left(\mathrm{X}_{2}\right)$, number of services per gestation $\left(\mathrm{X}_{3}\right)$, number of days dry prior to calving $\left(\mathrm{X}_{4}\right)$, and level of FCM yield in $\mathrm{kg}$ during the subsequent lactation period $\left(\mathrm{X}_{5}\right)$.

\begin{tabular}{|c|c|c|c|c|c|c|c|c|c|}
\hline$r_{12}$ & $0.4081 * * *$ & $r_{13}$ & $=0.0342$ & $r_{14}$ & $=0.1210$ & $r_{15}$ & $=0.0625$ & $r_{23}$ & 0.1088 \\
\hline$r_{12.3}$ & $0.4070^{* * *}$ & $r_{13.2}$ & $=-0.0112$ & $r_{14.2}$ & $=0.1214$ & $r_{15.2}$ & $=-0.0091$ & $r_{23.1}$ & 0.1040 \\
\hline$r_{12.4}$ & $0.4082 * * *$ & $r_{13.4}$ & $=\quad 0.0209$ & $r_{14.3}$ & $=0.1180$ & $r_{15.3}$ & $=0.0587$ & $r_{23.4}$ & 0.1067 \\
\hline$r_{12.5}$ & $0.4042 * * *$ & $r_{13.5}$ & $=0.0266$ & $\mathrm{r}_{14.5}$ & $=0.1307$ & $r_{15.4}$ & $=0.0797$ & $\mathrm{r}_{23.5}$ & 0.0892 \\
\hline$r_{12.34}$ & $0.4083 * * *$ & $r_{13.24}$ & $=-0.0248$ & $r_{14.23}$ & $=0.1233$ & $r_{15.23}$ & $=-0.0079$ & $r_{23.14}$ & 0.1074 \\
\hline$r_{12.35}$ & $0.4035 * * *$ & $r_{13.25}$ & $=-0.0103$ & $r_{14.25}$ & $=0.1212$ & $r_{15.24}$ & $=0.0077$ & $r_{23.15}$ & 0.0858 \\
\hline$r_{12.45}$ & $0.4017 * * *$ & $\mathrm{r}_{13.45}$ & $=0.0097$ & $\mathrm{r}_{14.35}$ & $=0.1283$ & $r_{15.34}$ & 0.0776 & $r_{23.45}$ & 0.0835 \\
\hline$r_{12.345}$ & $0.4022 * * *$ & $r_{13.245}$ & $=-0.0260$ & $r_{14.235}$ & $=0.1235$ & $r_{15.234}$ & 0.0111 & $r_{23.145}$ & 0.0868 \\
\hline $\mathbf{r}_{24}$ & $=0.0252$ & $r_{25}$ & $0.1734^{* *}$ & $r_{34}$ & $=0.1121$ & $r_{35}$ & 0.1250 & $r_{45}$ & $=-0.1330$ \\
\hline$r_{24.1}$ & $=-0.0265$ & $r_{25.1}$ & $0.1623^{*}$ & $r_{34.1}$ & $=0.1088$ & $r_{35.1}$ & 0.1232 & $r_{45.1}$ & $=-0.1418$ \\
\hline$r_{24.3}$ & $=0.0132$ & $r_{25.3}$ & $0.1620^{*}$ & $r_{34.2}$ & $=0.1100$ & $r_{35.2}$ & 0.1084 & $r_{45.2}$ & $=-0.1394$ \\
\hline$r_{24.5}$ & $=0.0493$ & $r_{25.4}$ & $0.1783 * *$ & $r_{34.5}$ & $=0.1308$ & $r_{35.4}$ & 0.1420 & $r_{45.3}$ & $=-0.1491$ \\
\hline$r_{24.13}$ & $=-0.0383$ & $r_{25.13}$ & $0.1515^{*}$ & $r_{34.12}$ & $=0.1121$ & $r_{35.12}$ & 0.1084 & $r_{45.12}$ & $=-0.1393$ \\
\hline$r_{24.15}$ & $=-0.0035$ & $r_{25.14}$ & $0.1602^{*}$ & $r_{34.15}$ & $=0.1284$ & $r_{35.14}$ & 0.1408 & $r_{45.13}$ & $=-0.1573$ \\
\hline $\mathrm{r}_{24.35}$ & $=0.0382$ & $r_{25.34}$ & $0.1658^{*}$ & $r_{34.25}$ & $=0.1270$ & $r_{35.34}$ & 0.1257 & $r_{45.23}$ & $=-0.1532$ \\
\hline$r_{24.135}$ & $=-0.0148$ & $r_{25.134}$ & $0.1474 *$ & $r_{34.125}$ & $=0.1292$ & $r_{35.124}$ & 0.1259 & $r_{45.123}$ & $=-0.1533^{*}$ \\
\hline$* *$ & & & & & & & & & \\
\hline$*$ & & & & & & & & & \\
\hline
\end{tabular}

The equations for estimating the birth weight of the calf in $\mathrm{kg}\left(\mathrm{X}_{1}\right)$, when the live weight of the dam in $\mathrm{kg}\left(\mathrm{X}_{2}\right)$ is known, were as follows:

Entire material

$\begin{array}{lll}\text { Both sexes } & (\mathrm{N}=225) & \mathrm{X}_{1}=17.2+0.03447 \mathrm{X}_{2} \\ \text { Males } & (\mathrm{N}=111) & \mathrm{X}_{1}=19.5+0.03133 \mathrm{X}_{2} \\ \text { Females } & (\mathrm{N}=114) & \mathrm{X}_{1}=12.9+0.04040 \mathrm{X}_{2}\end{array}$

Material from which the first calvers have been excluded

$\begin{array}{lll}\text { Both sexes } & (\mathrm{N}=169) & \mathrm{X}_{1}=18.9+0.03089 \mathrm{X}_{2} \\ \text { Males } & (\mathrm{N}=82) & \mathrm{X}_{1}=15.5+0.03919 \mathrm{X}_{2} \\ \text { Females } & (\mathrm{N}=87) & \mathrm{X}_{1}=21.0+0.02537 \mathrm{X}_{2}\end{array}$

According to the equation obtained from the entire material, the birth weight in both sexes increased by $34.47 \mathrm{~g}$ (males $31.33 \mathrm{~g}$ and females $40.40 \mathrm{~g}$ ) when the live weight of the dam increased by $1 \mathrm{~kg}$. After excluding the first calvers, the corresponding increase of $30.89 \mathrm{~g}$ in the birth weight obtained for both sexes was slightly lower and the extent of increase in males $(39.19 \mathrm{~g})$ and females $(25.37 \mathrm{~g})$ was reversed, a phenomenon which can be understood by examining the results presented in Table 2 .

In addition to the above results, the birth weight of the calf was found to be more closely correlated with the live weight of the dam at the 1st, 2nd, and 3rd calvings than at the 4 th and later calvings.

\section{Discussion}

According to Petraitis et al. (1967), female calves heavy at birth tended to be better milk producers at an adult age than light ones. In dairy-beef production, the birth weight 
of male calves is of special interest since the calves that are large at birth usually also make the fastest gains. The birth weight $\left(\mathrm{X}_{1}\right)$ in a group of 52 Ayrshire males was in a significant $(\mathrm{P}<0.001)$ and positive correlation with the live weight $\left(\mathrm{X}_{2}\right)\left(\mathrm{r}_{12}=0.5834\right)$ and the carcass weight $\left(\mathrm{X}_{3}\right)\left(\mathrm{r}_{13}=0.5129\right)$ attained by the age of six months. In another similar study with 74 Ayrshire males the respective correlations were: $r_{12}=0.5315$ and $\mathrm{r}_{13}=0.5468(\mathrm{P}<0.001)$ (writer's observations). MÄKELÄ (1959) noted a similar correlation $\left(r_{12}=0.55\right)$ in the female Ayrshires respectively.

$\mathrm{S}$ e x. The mean birth weight of the male calves $(35.2 \mathrm{~kg})$ in this study was significantly $(\mathrm{P}<0.005)$ higher than that of the females $(33.4 \mathrm{~kg})$ (Table 1), the sex difference being $1.8 \mathrm{~kg}$. Earlier in the same herd, MäkeL 299 male calves was $34.5 \mathrm{~kg}$ and that of 288 females $32.1 \mathrm{~kg}$, the sex difference of $2.4 \mathrm{~kg}$ being highly significant $(\mathrm{P}<0.001)$. The mean birth weight of 587 single calves was $33.3 \mathrm{~kg}$ in the study of MÄKELÄ, whereas in this study the mean value of 225 calves was $1.3 \mathrm{~kg}$ higher, i.e. $34.6 \mathrm{~kg}$. The proportion of calves born to the first calvers was approximately $1 / 4$ of all cases in both studies, but the age of the heifers at first calving has decreased by $1-2$ months during the last few years. This slight increase in the birth weight of the calves in the said herd might be due to the fact that the heifers and cows have been fed lately somewhat more intensively during few weeks prior to parturition compared to the feeding practised several years ago. Moreover, only calves born to the regular cows were included in the present study, whereas MÄKELÄ's data included also calves born to cows with calving intervals exeeding 15 months. In this study, the mean live weight of the male-dams was $502 \mathrm{~kg}$ and that of the female-dams $507 \mathrm{~kg}$. Since Märelä did not mention the live weights of the cows in his data, it is not known whether the size of the dams has been changed since 1950's. In the present data the mean number of services preceding the birth of a male was 1.71 and that of a female 1.54, the length of the dry period was 55.51 and 50.08 days respectively. The mean FCM yield of the male-dams was 5958 and that of the female-dams $5993 \mathrm{~kg}$ during the subsequent lactation period.

$\mathrm{S}$ e a s o n. Season affected significantly the birth weight of the calves in this study (Table 1), the highest mean value occurring in calves born during the first half of the year. The mean birth weight was lowest in July-September when also the live weight of the cows was at its lowest. The weight of the calf calculated as a percentage from the live weight of the dam was not, however, influenced by the season of birth indicating that the seasonal changes in the size of the calf at birth have been proportional to the changes in the live weight of the dam.

Feeding of the cows in question has been very intensive during the stall-feeding period (ref. Kossila 1967, p. 32-36). Even though the transition period has lasted from 1 to 2 weeks, and in addition to good quality pasture grass ad lib., the cows have received from 1 to 4 or $5 \mathrm{~kg}$ low protein concentrates (oats, barley) per day, according to their milk yield, they have lost weight after being turned out to pasture. The mean live weight of the cows in the present material was $516 \mathrm{~kg}$ in April-June and $40 \mathrm{~kg}$ less, i.e. $476 \mathrm{~kg}$, in July-September. The milk yield of the last mentioned cows did not significantly differ from the yield of cows that had calved during other seasons (Table 1). In the same herd, MäKELÄ (1962), noted lower peak yields during the grazing period than during the stall feeding period. Apparently there has been an overall decrease in the productional efficiency of cows during the summer months caused by the changes in the level of energy intake, in 
the type of feed, in the amount of exercise, in the environmental climate, and in hormonal functions. According to Kossila (1964), the level of protein bound iodine in the blood serum of cows in the said herd was significantly influenced by the season, being at its lowest during July-August and highest during the spring months.

Calving number. As far as the calving number is concerned, the results of this study (Table 2) agree in general with some of those reported earlier (FITcH et al. 1925, Tyler et al. 1947, Venge 1948, Braude \& Walker 1949, Mäkelä \& Oittila 1955, MäKelÄ 1959, Nielsen 1964). The birth weight of Ayrshire calves at first calving was $31.19 \mathrm{~kg}(\mathrm{~N}=100)$ in the study of MäkEL $\mathrm{A}(1959)$ and $32.0 \mathrm{~kg}$ in this study (Table 2), and at the second calving $33.3 \mathrm{~kg}(\mathrm{~N}=100)$ and $33.6 \mathrm{~kg}$, respectively. MÄKelä \& OittilA (1955), reported a value of $34.16 \mathrm{~kg}(\mathrm{~N}=49)$ at the fourth calving, the corresponding value in this study being $35.8 \mathrm{~kg}$. In several studies the change in the birth weights from the 1st to the 2nd calving has been greater than the change from the 2nd to the 3rd., etc. This was not the case with the present data, perhaps due to the limited number of cases. Furthermore, it was noted that the birth weight, calculated as a percentage from the live weight of the dam, tended to be higher at the first three calvings than thereafter.

Correlation studies. The live weight of the dam appeared to be the only variable in the correlation studies which significantly affected the birth weight of the calf (Table 3). Part of this effect was apparently due to the tendency for the birth weight to increase with the number of dam's calvings, i.e. parallel with the increase in the live weight of the dams due to age (Table 2), and partly to the parallel seasonal fluctuations in the two variables (Table 1).

The corresponding correlations $\left(\mathrm{r}_{12}\right)$, calculated separately for the first-calvers, second calvers, etc., were considerably closer at the 1st, 2nd, and 3rd calvings compared with later calvings (writer's observation). The first three calvings in the present study included approximately $70 \%$ of all cases. In the study of MÄKELÄ \& OitTILA (1955), the correlation between the birth weight of the calf and the so-called normal weight (effect of the degree of fatness eliminated) of the dam was very low $\left(\mathrm{r}_{12}=0.113, \mathrm{~N}=136\right)$. Probably the birth weight of the calf is more closely correlated with the live weight than with this so called normal weight of the cow, since, according to MäKELÄ \& OrtTILA, fat cows tended to produce larger calves than lean ones.

In well fed, regular cows the length of the dry period and the number of services required per birth of a calf cannot be expected to influence markedly the birth weight. It might have been advisable to include also other variables, e.g. the length of the gestation period, the degree of fatness of the cow at calving time, the calving interval, peak milk yield, and/or persistency of lactation, into the correlation study. According to MÄKELÄ \& Ortrila (1955), the length of the gestation, even though positively correlated with the birth weight of the calf, was not influenced by the number of the dam's calvings in the said herd. The mean daily milk yield or 12 months' yield would have been obviously a more accurate indicator of the lactational ability of a cow compared to the FCM yield of the entire lactation period used in this study, since the calving interval, even in normal cows, may vary considerably in different individuals. Perhaps partly due to the method used in estimating the FCM yield in this study, practically no correlation $\left(\mathrm{r}_{12.345}=0.0111\right)$ was noted between the birth weight of the calf and the milk yield of the dam (Table 3 ).

The negative correlation, noted between the length of the dry period and the milk 
yield of the subsequent lactation period $\left(\mathrm{r}_{\mathbf{4 5 . 1 2 3}}=-0.1533\right)$ (Table 3$)$, has probably been partly due to the differences in the persistency of lactation in various individuals and partly due to the tendency of the dry period to become shorter and the milk yield larger with increasing calvings of the cows (Table 2).

\section{Su m mary}

Sources of variation in the birth weights of 225 single Ayrshire calves, born to regular cows (calving interval less than 15 months) in the dairy herd of the Viik Experimental Farm, were studied. The mean birth weight $(35.2 \mathrm{~kg})$ of 111 male calves was significantly $(\mathrm{P}<0.005)$ higher than that $(33.4 \mathrm{~kg})$ of $114 \mathrm{females}$. The relative birth weight calculated as a percentage from the live weight of the dam was $7.05 \%$ in males and $6.55 \%$ in females, on an average.

The smallest calves were born in July-September $(32.3 \mathrm{~kg})$ and the heaviest in AprilJune $(35.5 \mathrm{~kg})$, this seasonal trend being significant $(\mathrm{P}<0.001)$. However, the relative birth weight of combined sexes remained constant throughout the year.

The number of the dam's calvings affected significantly the birth weight, which was low at the first calving $(32.0 \mathrm{~kg})$ and also at the 6 th or subsequent calvings $(33.6 \mathrm{~kg})$. Maximum birth weight of males $(39.2 \mathrm{~kg}$ ) was attained at the 5 th calving and that of females $(36.1 \mathrm{~kg}$ ) at the 3rd calving. The relative birth weight was highest in the males $(7.44 \%)$ at first calving and lowest in the females $(5.93 \%)$ at the 6 th or subsequent calvings.

The relationships between the birth weight of the calf $\left(\mathrm{X}_{1}\right)$, the live weight of the dam $\left(\mathrm{X}_{2}\right)$, the number of services per gestation resulting in the birth of the calf $\left(\mathrm{X}_{3}\right)$, the number of days dry prior to parturition $\left(\mathrm{X}_{4}\right)$, and the level of fat corrected milk (FCM) yield during the lactation period subsequent to calving $\left(\mathrm{X}_{5}\right)$, were investigated by means of calculating the coefficients of simple and partial correlations. The live weight of the dam was the only variable which significantly affected the birth weight of the calf $\left(\mathrm{r}_{12.345}=0.4022\right.$, $\mathrm{P}<0.001, \mathrm{~N}=225)$, the length of the dry period had a slight positive effect $\left(\mathrm{r}_{14.235}=\right.$ $0.1235)$. The correlations obtained separately for males were mostly of similar order as those obtained for females. Regression equations demonstrating the relationship between the birth weight of the calf and the live weight of the dam, are given.

Due to strong feeding of the cows, it is believed that the birth weights of the calves in the dairy herd of the Viik Experimental Farm are somewhat larger if compared with the overall values of the Ayrshire breed in Finland.

\section{REFERENCES}

Andersen, H. 1962. Sammanhaeng mellem draegtighedsperiodens laengde of kalvens fadelsevaegt. II. Sammanhaeng mellem moderensvaegt of kalvens fodelsevaegt. Årsberetning for Institut for Sterilitetsforskning. 155.

Bennett, J. A. 1959. An analysis of birth, weaning and feedlot performance data on beef cattle. Anim. Breed. Abstr. 27: 30.

BRAUde, R. \& WAlker, D. M. 1949. Mortality, weight and body measurements at birth of dairy Shorthorn calves. J. Agric. Sci. 35: 156. 
Croxton, F. E. \& Cowden, D. J. 1955. Applied General Statistics. 2nd ed. Pitman, London, XVI + 843 pp. Chapt. 21.

Frtch, J. B., McGillard, P. C. \& Drumm, G. M. 1925. Untersuchungen über das Geburtsgewicht und die Trächtigkeitsdauer von Milchvieh. Z. für Tier-Züchtung \& Züchtungsbiol. IV.

Foote, W. D., Tyler, W. J. \& Casida, L. E. 1959. Effect of some genetic and maternal environmental variations on birth weight and gestation length in Holstein cattle. J. Dairy Sci. 42: 305.

Hafez, E. S. E. 1968. Reproduction in Farm Animals. 2nd ed. Philadelphia, XII + 440 pp.

Knapp, B., Lambert, W. V. \& Black, W. H. 1940. Factors influencing length of gestation and birth weight in cattle. J. Agric. Res. 61: 277.

Kossit.A, V. 1964. Effects of season and stage of lactation on the protein bound iodine and total cholesterol in serum of dairy cows. J. Sci. Agric. Soc. Finland 35: 81-91.

- - 1967. On the weight and basic structural components of the thyroid in dairy cattle. Acta Agral. Fenn. 109, 2 pp. 57, 60-61.

Mukerji, S. K. \& ЕккA, S. T. 1962. Effect of some factors causing variation in the gestation period of Bachaur cows in Bihar breed. Anim. Breed. Abstr. 30: 351.

MÄKELÄ, A. 1959. Havaintoja ja laskelmia lehmävasikoitten sekä hiehojen kasvusta Viikin koetilan karjassa. J. Sci. Agric. Soc. Finland 31: 304-314.

- - 1962. The lactation curve of the cow at the ascending phase. Ibid. $34: 173-186$.

—- \& Ortril.A, R. 1955. Tiineysajan pituus Viikin opetus- ja koetilan Ayrshire-karjassa. Ibid. 27: $77-84$.

NiELsen, E. 1964. Nogle factorer som har indflydelse på kalvenes fødelsevaegt. Landbohøjskol. beretn. 338: $12-31$.

Novy, I. 1963. Study of the relations between the milk yield, the live weight of cows and the birth weight of calves at the Slovak Spotted cattle. Acta Universitalis Agric., Nitra, Facultas Agronomica VII: $137-147$.

Petcu, D. \& Calotoru, A. 1967. Twin calvings in dairy cattle. Lucr. stiint. Inst. Cerc. Zooteh. 25: $363-371$.

Petraitis, I. P., Zhal'nieryus, V. A. et al. 1967. The relation between the vitality of cows and their birth weight. Vest. sel.-khoz. Nauki, Mosk. 12: 6: 66-68 (ref. D.S.A. 29 ab. 3351, 1967).

Roy, J. H. B. 1955. The calf. Its management, feeding and health. London. 79 pp.

Tyler, W. J., Chapman, A. B. \& Dickerson, G. E. 1947. Sources of variation in the birth weight of Holstein Friesian calves. J. Dairy Sci. 30: 483.

VENGE, O. 1948. Forskellige faktorers invirkning på fødelsvaegten of kalve. Nord. Jordbr. Forskn. 208.

\title{
SELOSTUS
}

\section{AYRSHIRE-VASIKOIDEN SYNTYMÄPAINON VAIHTELUIHIN VAIKUTTAVISTA TEKIJÖISTÄ}

\author{
Vappu Kossila ja Pirkko Taskinen \\ Helsingin yliopiston kotieläintieteen laitos
}

Syntymäpainon vaihteluihin vaikuttavia tekijöitä tutkittiin 56:n $2-8$ kertaa perättäin säännöllisesti poikineen lehmän 225 yksinään syntynyttä, täysiaikaista, tervettä vasikkaa käsittävästä aineistosta, joka oli kerätty Viikin opetus- ja koetilan karjasta. 225:n vasikan syntymäpäino oli keskim. $34.6 \mathrm{~kg}, 111: \mathrm{n}$ sonnivasikan keskim. $35.2 \mathrm{~kg}$ ja 114:n lehmävasikan keskim. $33.5 \mathrm{~kg}$. Sukupuolien välinen painoero oli merkittävä $(\mathrm{P}<0.005)$.

Eri vuodenaikoina syntyneillä vasikoilla havaittiin painoeroja; pienin keskim. syntymäpaino $(32.3 \mathrm{~kg})$ oli heinä-syyskuussa syntyneillä $(\uparrow+\delta)$ ja korkein $(35.5 \mathrm{~kg})$ vastaavasti maalis-kesäkuussa syntyneillä $\left(\uparrow+\delta^{*}\right)$ ko. keskiarvojen eron ollessa erittäin merkittävän $(\mathrm{P}<0.001)$. 
Emän poikimakertojen lukumäärä vaikutti vasikan syntymäpainoon merkittävästi. Ensikoilla (32.0 kg) ja yli 5 kertaa $(33.6 \mathrm{~kg})$ poikineilla tavattiin pienimmät ja $3-5$ kertaa poikineilla $(35.8-36.4 \mathrm{~kg})$ suurimmat syntymäpainot $(\hat{\sigma}+\uparrow)$. Sonnivasikoiden syntymäpainon todettiin kohoavan 1.:stä (33.2 kg) 5.:teen $(39.2 \mathrm{~kg})$ ja lehmävasikoiden 1.:stä $(30.7 \mathrm{~kg}) 3$. teen $(36.1 \mathrm{~kg})$ poikimiseen.

Sonnivasikoiden emät painoivat 5. päivänä poikimisen jälkeen keskim. 502 kg ja lehmävasikoiden $507 \mathrm{~kg}$. Vasikoiden syntymäpaino prosentteina emän elopainosta (= suhteellinen syntymäpaino) oli sonnivasikoilla keskim. $7.05 \%$ ja lehmävasikoilla $6.55 \%$. Vuodenaika ei vaikuttanut lainkaan vasikan $\left(\delta^{\star}+\uparrow\right)$ suhteelliseen syntymäpainoon, mistä päätellen emien elopainon vuodenaikavaihtelut olivat olleet yhdensuuntaisia vasikoiden syntymäpainovaihteluiden kanssa. Vasikan suhteellinen paino oli kolmena ensimmäisenä poikimakertana korkeampi verrattuna myöhempiin poikimisiin.

Aineistosta laskettiin tilastollisesti seuraavien tekijöiden väliset vuorosuhdekertoimet: vasikan syntymäpaino $\left(\mathrm{X}_{1}\right)$, emän elopaino 5. poikimisen jälkeisenä päivänä $\left(\mathrm{X}_{2}\right)$, astutuskertojen lukumäärä sitä tiineyttä kohden, josta ko. vasikka oli syntynyt $\left(\mathrm{X}_{3}\right)$, ummessaoloajan pituus ennen ko. vasikan syntymää $\left(\mathrm{X}_{4}\right)$ ja poikimista seuranneen koko laktaatiokauden 4-prosenttiseksi muunnettu maitotuotos $\left(\mathrm{X}_{\mathrm{b}}\right)$. Ko. tekijöistä ainoastaan emän elopainolla oli merkittävä $(\mathrm{P}<0.001)$ vaikutus vasikan syntymäpainoon $\left(\mathrm{r}_{12.345}=\right.$ $0.4022)$. Astutuskertojen lukumäärällä oli varsin vähäinen vaikutus $\left(r_{13.245}=-0.0260\right)$. Ummessaoloajan pidentyessä vasikan syntymäpaino pyrki kohoamaan $\left(\mathrm{r}_{14.235}=0.1235\right)$ joskaan ei merkittävästi. Vasikan syntymäpainon ja syntymää seuranneen laktaatiokauden 4-prosenttisen maitotuotoksen välillä ei havaittu juuri mitään vuorosuhdetta $\left(r_{15.234}=0.0111\right)$. Sonni- ja lehmävasikoille erikseen lasketuissa vuorosuhteissa ei ilmennyt mainittavia eroja verrattuna koko aineistosta saatuihin vastaaviin vuorosuhdekertoimiin.

Tutkimuksessa on esitetty useita vasikan painon riippuvuutta emän painosta kuvaavia regressioyhtälöitä, joista koko aineistolle $(\mathrm{N}=225)$ saatu oli seuraava:

$$
\mathrm{X}_{1}=17.2+0.03447 \mathrm{X}_{2}
$$

$\left(\mathrm{X}_{1}=\right.$ vasikan syntymäpaino, $\mathrm{kg} ; \mathrm{X}_{2}=$ emän elopaino, $\left.\mathrm{kg}\right)$. Yhtälön mukaan vasikan syntymäpaino on kohonnut koko aineistossa keskim. $34.47 \mathrm{~g}$ emän elopainon kohotessa $1 \mathrm{~kg}$ :lla. 